\title{
The annual change of environmental gamma radiation in Bitlis
}

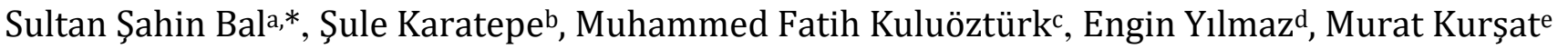 \\ a Bitlis Eren University, Department of Physics, TR-13000, Bitlis Turkey \\ $\mathrm{b}$ Bitlis Eren University, Vocational School of Hizan, TR-13000, Bitlis Turkey \\ c Bitlis Eren University, Department of Electrical and Electronics Engineering, TR-13000, Bitlis Turkey \\ d Bitlis Eren University, Department of Chemistry, TR-13000, Bitlis Turkey \\ e Bitlis Eren University, Department of Biology, TR-13000, Bitlis Turkey
}

\section{A RT I CLE IN FO}

\section{Article history:}

Received 14 March 2018

Received in revised form 24 May2018

Accepted 24 May2018

\section{Keywords:}

Radiation

Environmental Gamma

Bitlis

\begin{abstract}
A B S T RACT
In this study, the environmental gamma radiation starting at December, 2014 through November, 2015 were measured at different 16 points. The environmental gamma radiation measurement was made from the ground and one meter above the surface by using portable gamma survey meter which consisted of $\mathrm{NaI}(\mathrm{Tl})$ scintillation detector. The lowest values of environmental gamma radiation are $0.041 \mu \mathrm{Sv} / \mathrm{h}$ at ground level and $0.035 \mu \mathrm{Sv} / \mathrm{h}$ at the one-meter level on the location XIII, the highest values of environmental gamma radiation are $0.478 \mu \mathrm{Sv} / \mathrm{h}$ at the ground level and $0.453 \mu \mathrm{Sv} / \mathrm{h}$ at the one-meter level on the location XVI.
\end{abstract}

\section{Introduction}

There are two main contributions determining the level of exposure to natural radiation. The first of these are highenergy cosmic rays reaching to the earth's atmosphere. The other is that there are radioactive elements in the crust of the World (environment, even in the human body) [1]. The contribution of natural radiation of cosmic rays varies with altitude, as one climbs up from sea level to remain constant in certain latitude [2].

The basic level of natural radiation varies depending on the geological and geographical features of area. Soil and rock mineralogical structure with geographical altitude affects the basic radiation levels in the region [3].

Natural radionuclides as $238 \mathrm{U},{ }^{232} \mathrm{Th}$ and ${ }^{40} \mathrm{~K}$ in the soil causes to be radioactive of the soil. Natural radionuclides are mostly found in high concentrations in volcanic rocks (especially in granite), pegmatites and hydrothermal deposits. Water constantly interacts with the soil and rocks around it. Therefore, the transfer possibility of interacting waters with them of the natural radionuclides in the soil and rocks is very high [4].

The soil contains an amount of radiation because the main materials of it carry radioactive isotopes. Radionuclides that are naturally present in the Earth's crust formation and their degradation products from the major part of the environmental radiation emitting gamma rays. $\alpha, \beta$ and $\gamma$ as long-lived radionuclides such as ${ }^{238} \mathrm{U},{ }^{232} \mathrm{Th}$ and ${ }^{40} \mathrm{~K}$ are the starting radioisotopes of source of the radiation of terrestrial. The mass activity concentration of these natural radionuclides varies according to the type of soil and rock [57]. The mass activity concentration is radiation intensity corresponds to the absorbed dose in the air on $1 \mathrm{~m}$ height from the ground [5]. Thus, the measured radiation dose in the air is closely related to concentrations of radionuclides in the soil.

\footnotetext{
* Corresponding author.

Tel.: +0 434222 0020-2314;

E-mail address: sahin.sultan@gmail.com
} 


\section{Experimental}

The environmental gamma measurements in the various locations (16 points) was made by Dose Rate Meter that it is containing scintillation counter having to 2"x2" $\mathrm{NaI}(\mathrm{Tl})$ crystal at ground and $1 \mathrm{~m}$ level height [8]. The city center and its districts were easily screened because of the system used is portable.

Locations of 16 points in Bitlis area, where the environmental gamma measurements conducted, are presented in Table 1.

Table 1. Location of environmental gamma measurement points [9].

\begin{tabular}{lrr}
\hline & Latitude (North) & Longitude (East) \\
\hline I & 38.33451 & 42.00472 \\
II & 38.32286 & 42.01657 \\
III & 38.33052 & 42.01483 \\
IV & 38.41749 & 41.91641 \\
V & 38.41745 & 41.91586 \\
VI & 38.41175 & 42.11722 \\
VII & 38.58592 & 42.00056 \\
VIII & 38.39302 & 42.26883 \\
IX & 38.39928 & 42.26320 \\
X & 38.48519 & 42.32428 \\
XI & 38.63133 & 42.44054 \\
XII & 38.84262 & 42.82970 \\
XIII & 38.78785 & 42.69599 \\
XIV & 38.74583 & 42.45415 \\
XV & 38.66603 & 42.30422 \\
XVI & 38.63527 & 42.24807 \\
\hline
\end{tabular}

\section{Results and Discussion}

Environmental gamma measurements were taken monthly periods on the ground and $1 \mathrm{~m}$ above the ground levels. The measurements made $1 \mathrm{~m}$ above the soil level and the ground are presented in Table 2 and Table 3.

The measurements made in $1 \mathrm{~m}$ above the soil level and the ground from December to November is shown in Figure 1Figure 6, from the data given in Table 2 and Table 3.

It is understood from Table 2, Table 3 and from Figure 2Figure 6 that the values in ground level, where gamma radiation is directly emitted from the soil, were higher (43.23 $\%$ ) than the values that were measured at $1 \mathrm{~m}$ level. However, it was found that the measured environmental gamma values in August on measurement points in the both ground and $1 \mathrm{~m}$ height level were highest value and the measured environmental gamma values both in January and in February on measurement points in both ground and $1 \mathrm{~m}$ height level were the lowest value.

The number XVIth measuring point is located higher than the other measuring points. The point XVI was chosen above one of volcanic mountains (height is $2.935 \mathrm{~m}$ ) that the latest active in Turkey. To be this way of results is the expected case because the contribution to natural radiation of cosmic rays varies with height; this contribution remains constant moving up sea level on certain latitude [2], more elevation locations are exposed to more radiation than less elevation locations [10].

Cosmic radiation consists of electromagnetic radiation or released particles at different energy and different charges. Their origins are also different. Their density decreases when it reaches the upper layers of the atmosphere to sea level [2, 11]. Being the lowest of environmental gamma values measured at the measurement point XIII may be caused by less effect of electromagnetic waves (this point is further away from the other point of to residential areas) and not intense electromagnetic reflections. 
Bitlis Eren University Journal of Science and Technology 8(1) (2018) 19-23

Table 2. The values of environmental gamma measurement in the ground and $1 \mathrm{~m}$ height level (December 2014-May 2015).

\begin{tabular}{|c|c|c|c|c|c|c|c|c|c|c|c|c|}
\hline & \multicolumn{2}{|c|}{$\begin{array}{l}\text { December } \\
(\mu \mathrm{Sv} / \mathrm{h})\end{array}$} & \multicolumn{2}{|l|}{$\begin{array}{l}\text { January } \\
(\mu \mathrm{Sv} / \mathrm{h})\end{array}$} & \multicolumn{2}{|c|}{$\begin{array}{l}\text { February } \\
(\mu \mathrm{Sv} / \mathrm{h})\end{array}$} & \multicolumn{2}{|l|}{$\begin{array}{l}\text { March } \\
(\mu \mathrm{Sv} / \mathrm{h})\end{array}$} & \multicolumn{2}{|l|}{$\begin{array}{l}\text { April } \\
(\mu \mathrm{Sv} / \mathrm{h})\end{array}$} & \multicolumn{2}{|l|}{$\begin{array}{l}\text { May } \\
(\mu \mathrm{Sv} / \mathrm{h})\end{array}$} \\
\hline & Ground & $1 \mathrm{~m}$ & Ground & $1 \mathrm{~m}$ & Ground & $1 \mathrm{~m}$ & Ground & $1 \mathrm{~m}$ & Ground & $1 \mathrm{~m}$ & Ground & $1 \mathrm{~m}$ \\
\hline I & 0.229 & 0.227 & 0.179 & 0.172 & 0.169 & 0.165 & 0.170 & 0.166 & 0.211 & 0.207 & 0.183 & 0.171 \\
\hline II & 0.208 & 0.216 & - & - & 0.173 & 0.169 & 0.197 & 0.182 & 0.241 & 0.220 & 0.234 & 0.237 \\
\hline III & 0.221 & 0.198 & 0.141 & 0.157 & 0.194 & 0.183 & 0.193 & 0.181 & 0.215 & 0.206 & 0.213 & 0.215 \\
\hline IV & 0.217 & 0.205 & 0.205 & 0.199 & 0.159 & 0.145 & 0.182 & 0.172 & 0.206 & 0.194 & 0.219 & 0.209 \\
\hline V & 0.140 & 0.147 & 0.126 & 0.133 & 0.129 & 0.122 & 0.131 & 0.129 & 0.146 & 0.145 & 0.156 & 0.160 \\
\hline VI & 0.350 & 0.357 & 0.340 & 0.375 & 0.323 & 0.257 & 0.442 & 0.305 & 0.364 & 0.368 & 0.362 & 0.356 \\
\hline VII & 0.232 & 0.221 & 0.090 & 0.098 & 0.155 & 0.142 & 0.170 & 0.157 & 0.165 & 0.151 & 0.158 & 0.146 \\
\hline VIII & 0.199 & 0.194 & 0.145 & 0.137 & 0.162 & 0.156 & 0.189 & 0.175 & 0.198 & 0.194 & 0.218 & 0.195 \\
\hline IX & 0.234 & 0.221 & 0.150 & 0.146 & 0.175 & 0.165 & 0.209 & 0.200 & 0.197 & 0.184 & 0.223 & 0.206 \\
\hline $\mathrm{X}$ & 0.268 & 0.244 & 0.165 & 0.147 & 0.194 & 0.186 & 0.241 & 0.208 & 0.223 & 0.196 & 0.264 & 0.248 \\
\hline XI & 0.242 & 0.217 & 0.204 & 0.202 & 0.234 & 0.223 & 0.260 & 0.231 & 0.300 & 0.263 & 0.272 & 0.240 \\
\hline XII & 0.251 & 0.226 & 0.199 & 0.197 & 0.177 & 0.165 & 0.146 & 0.168 & 0.235 & 0.232 & 0.314 & 0.278 \\
\hline XIII & 0.134 & 0.133 & 0.105 & 0.101 & 0.095 & 0.086 & 0.093 & 0.086 & 0.135 & 0.129 & 0.127 & 0.115 \\
\hline XIV & 0.227 & 0.204 & 0.230 & 0.211 & 0.222 & 0.198 & 0.217 & 0.207 & 0.247 & 0.245 & 0.235 & 0.211 \\
\hline XV & 0.252 & 0.226 & - & - & - & - & 0.244 & 0.215 & 0.198 & 0.204 & 0.296 & 0.256 \\
\hline XVI & 0.404 & 0.375 & 0.478 & 0.453 & - & - & - & - & - & - & 0.356 & 0.317 \\
\hline
\end{tabular}

Table 3. The values of environmental gamma measurement in the ground and $1 \mathrm{~m}$ height level (June- November 2015).

\begin{tabular}{|c|c|c|c|c|c|c|c|c|c|c|c|c|}
\hline & \multicolumn{2}{|l|}{$\begin{array}{l}\text { June } \\
(\mu \mathrm{Sv} / \mathrm{h})\end{array}$} & \multicolumn{2}{|l|}{$\begin{array}{l}\text { July } \\
(\mu \mathrm{Sv} / \mathrm{h})\end{array}$} & \multicolumn{2}{|l|}{$\begin{array}{l}\text { August } \\
(\mu \mathrm{Sv} / \mathrm{h})\end{array}$} & \multicolumn{2}{|c|}{$\begin{array}{l}\text { September } \\
(\mu \mathrm{Sv} / \mathrm{h})\end{array}$} & \multicolumn{2}{|l|}{$\begin{array}{l}\text { October } \\
(\mu \mathrm{Sv} / \mathrm{h})\end{array}$} & \multicolumn{2}{|c|}{$\begin{array}{l}\text { November } \\
(\mu \mathrm{Sv} / \mathrm{h})\end{array}$} \\
\hline & Ground & $1 \mathrm{~m}$ & Ground & $1 \mathrm{~m}$ & Ground & $1 \mathrm{~m}$ & Ground & $1 \mathrm{~m}$ & Ground & $1 \mathrm{~m}$ & Ground & $1 \mathrm{~m}$ \\
\hline I & 0.117 & 0.162 & 0.192 & 0.191 & 0.207 & 0.189 & 0.234 & 0.211 & 0.157 & 0.150 & 0.108 & 0.092 \\
\hline II & 0.249 & 0.240 & 0.287 & 0.261 & 0.254 & 0.238 & 0.245 & 0.227 & 0.169 & 0.162 & 0.186 & 0.157 \\
\hline III & 0.192 & 0.185 & 0.188 & 0.196 & 0.264 & 0.262 & 0.211 & 0.190 & 0.148 & 0.139 & 0.097 & 0.094 \\
\hline IV & 0.218 & 0.199 & 0.310 & 0.285 & 0.289 & 0.285 & 0.252 & 0.246 & 0.139 & 0.125 & 0.125 & 0.103 \\
\hline V & 0.185 & 0.177 & 0.225 & 0.228 & 0.235 & 0.220 & 0.193 & 0.173 & 0.073 & 0.075 & 0.063 & 0.044 \\
\hline VI & 0.345 & 0.341 & 0.449 & 0.435 & 0.451 & 0.431 & 0.424 & 0.407 & 0.268 & 0.253 & 0.264 & 0.254 \\
\hline VII & 0.243 & 0.226 & 0.296 & 0.272 & 0.251 & 0.225 & 0.281 & 0.268 & 0.175 & 0.163 & 0.144 & 0.134 \\
\hline VIII & 0.255 & 0.247 & 0.310 & 0.313 & 0.261 & 0.243 & 0.251 & 0.239 & 0.164 & 0.145 & 0.134 & 0.125 \\
\hline IX & 0.275 & 0.264 & 0.272 & 0.280 & 0.243 & 0.239 & 0.302 & 0.288 & 0.193 & 0.165 & 0.164 & 0.144 \\
\hline $\mathrm{X}$ & 0.302 & 0.291 & 0.313 & 0.280 & 0.295 & 0.282 & 0.314 & 0.306 & 0.255 & 0.236 & 0.201 & 0.165 \\
\hline XI & 0.319 & 0.305 & 0.386 & 0.377 & 0.361 & 0.328 & 0.398 & 0.369 & 0.280 & 0.253 & 0.197 & 0.164 \\
\hline XII & 0.375 & 0.336 & 0.400 & 0.357 & 0.345 & 0.311 & 0.335 & 0.325 & 0.248 & 0.207 & 0.253 & 0.219 \\
\hline XIII & 0.198 & 0.178 & 0.196 & 0.186 & 0.154 & 0151 & 0.137 & 0.121 & 0.079 & 0.068 & 0.041 & 0.035 \\
\hline XIV & 0.359 & 0.309 & 0.374 & 0.344 & 0.313 & 0.301 & 0.295 & 0.266 & 0.192 & 0.174 & 0.177 & 0.167 \\
\hline XV & 0.343 & 0.315 & 0.460 & 0.410 & 0.318 & 0.283 & 0.297 & 0.281 & 0.204 & 0.187 & 0.120 & 0.145 \\
\hline XVI & 0.397 & 0.378 & 0.287 & 0.332 & 0.448 & 0.403 & 0.426 & 0.399 & 0.325 & 0.293 & 0.315 & 0.260 \\
\hline
\end{tabular}



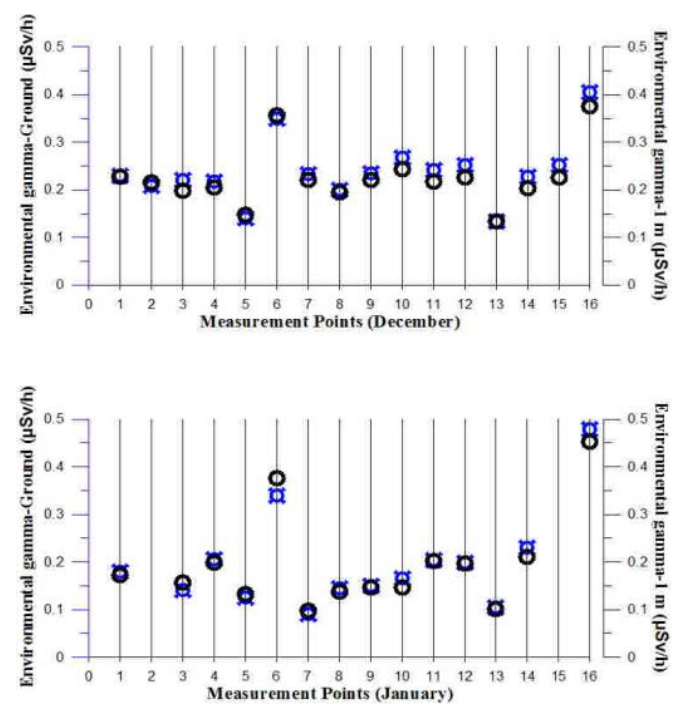

Figure 1. Environmental gamma variation at ground $(x)$ and $1 \mathrm{~m}$ level ( 0 ) on the 16 points in December and January.
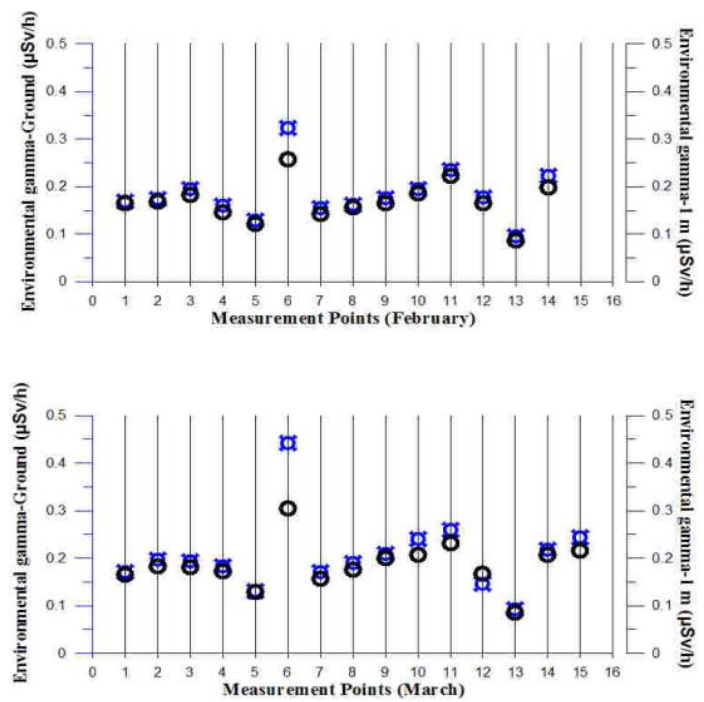

Figure 2. Environmental gamma variation at ground $(\mathfrak{a})$ and $1 \mathrm{~m}$ level (०) on the 16 points in February and March.

\section{Conclusion}

Environmental gamma values were measured low progressed towards the winter season due to not to perpendicular and of an angle the sun's rays begin to come to earth.

Environmental gamma values measured at $1 \mathrm{~m}$ distance gives information about the concentration of radioactivity in the soil of the measurement point [7]. According to this study, the average gamma dose rate values were measured approximately $0.23 \mu \mathrm{Svh}^{-1}$.
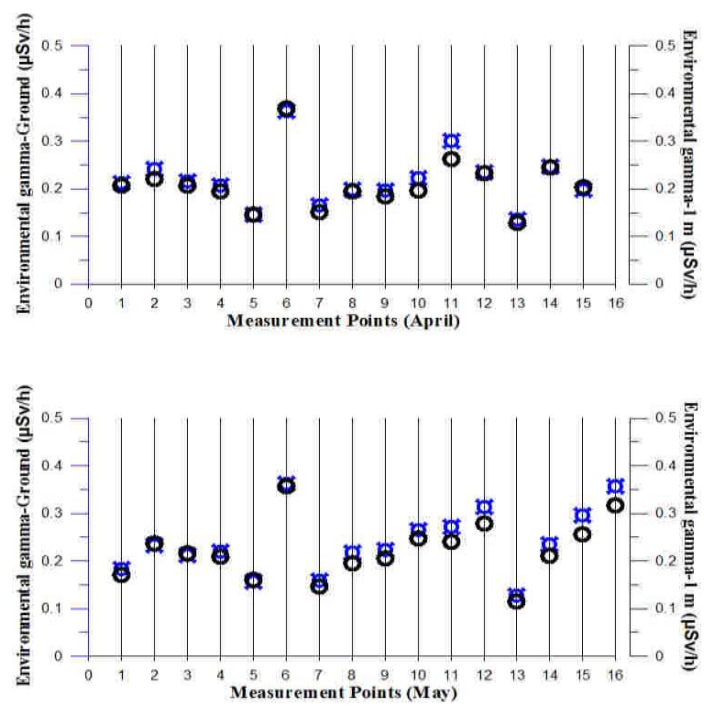

Figure 3. Environmental gamma variation at ground $(\mathfrak{x})$ and $1 \mathrm{~m}$ level (०) on the 16 points in April and May.
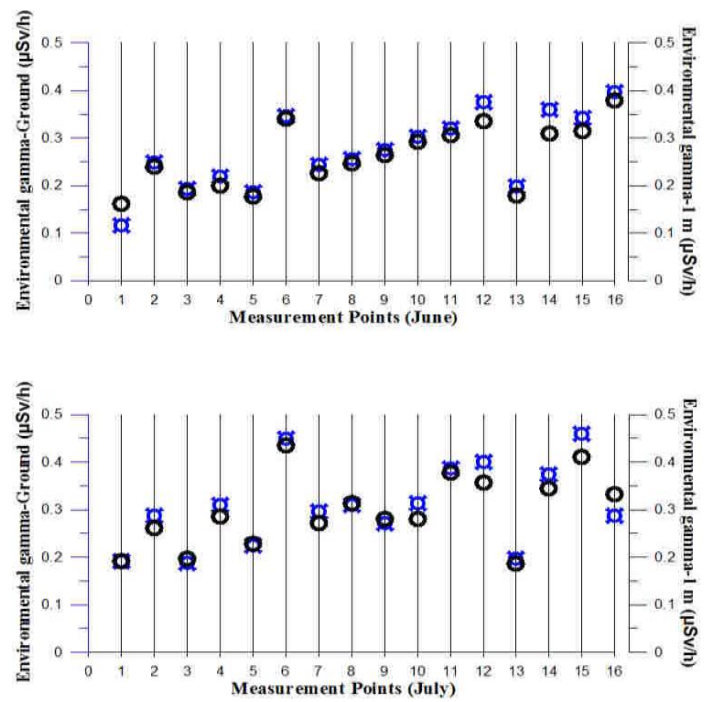

Figure 4. Environmental gamma variation at ground $(\mathrm{x})$ and $1 \mathrm{~m}$ level (O) on the 16 points in June and July.

According to UNSCEAR $(1993,2000)$ report, the global average of the measured gamma dose rate ranged from 10 to $200 \mathrm{nGyh}^{-1}$. In this study, the averages of measurements taken at ground level are $233.15 \mathrm{nGyh}^{-1}$ and the averages of measurements taken at $1 \mathrm{~m}$ level are $218.79 \mathrm{nGyh}^{-1}$. When the obtained results are compared with gamma dose rate average values world; it is seen that the gamma dose rates is at a level above the world average. The cause of the high levels of gamma dose rates may be geological features of the region, the absence of fault zones and the residential area of higher altitudes. The radioactivity on the fault zone is generally higher than other places, and radioactivity can be changed with the seismological aspects of activity of the fault [7]. 

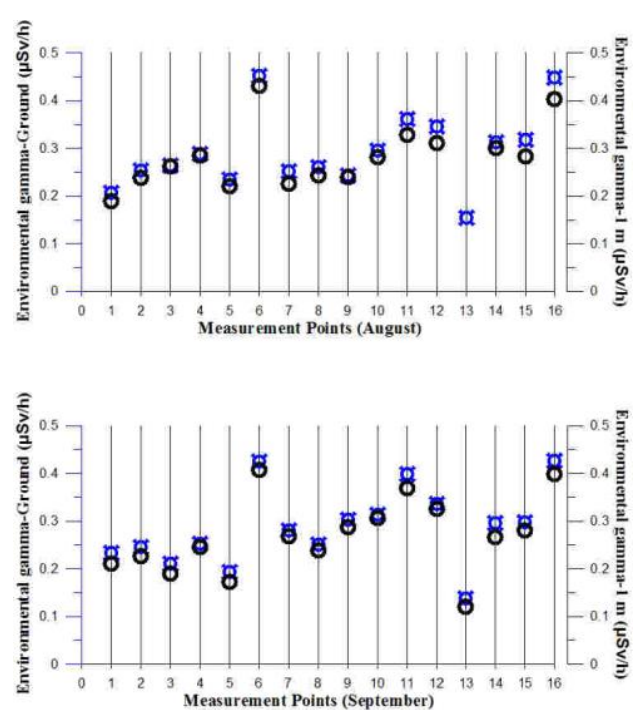

Figure 5. Environmental gamma variation at ground $(\boldsymbol{a})$ and $1 \mathrm{~m}$ level (O) on the 16 points in August and September.
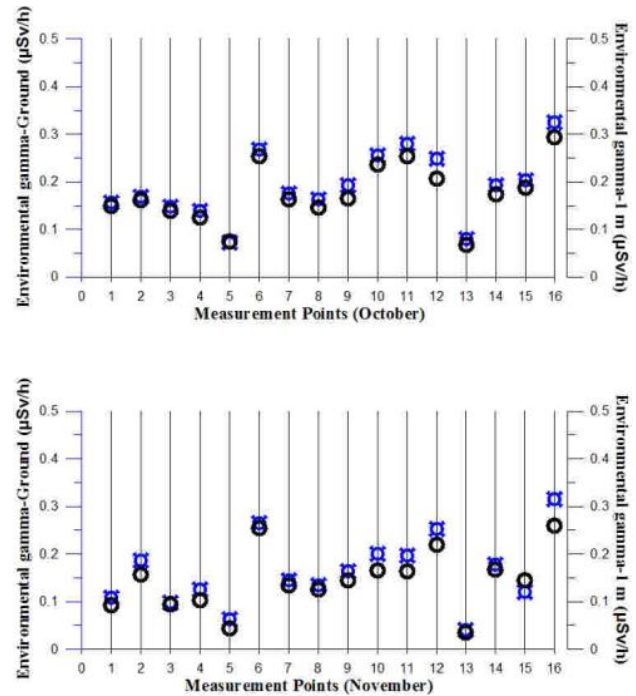

Figure 6. Environmental gamma variation at ground $(\mathfrak{a})$ and $1 \mathrm{~m}$ level $(\circ)$ on the 16 points in October and November.

\section{Acknowledgements}

This work was supported by BEBAP with project number is 2014.06.

\section{References}

[1] Kaya, S., Karabıdak, S. M., and Çevik, U., 2015. Determination of Natural (226Ra, 232Ta and 40K) and Artificial (137CS) Radioactivity Concentrations in Soil and Moss Samples Collected from Around Gümüşhane, GÜFBED/GUSTIJ, 5 (1): 24-3.

[2] UNSCEAR, 2000. Sources and effects of ionizing radiation. Report to General Assembly, with Scientific Annexes. United Nations, New York.

[3] Değerlier, M., and Peștemalcı, V., 2012. Determination of Enviromental Natural Radioactivity of Adana and the Annual Effective Dose Equivalent Due to Natural Radiations, Çukurova University Journal of Science And Engineering, 27-5.

[4] Şahin Bal, S., and Doğru, M., 2012. Determination of Radioactivity Concentration in the Sivrice (Elazığ) Fault Zone, IZYEF, 71, İzmir, 19-23 June, Symposium Abstracts book, p. 71.

[5] Karahan, G., 1997. Determination of Environmental Natural Radioactivity of İstanbul and the Annual Effective Dose Equivalent due to Natural Radiations, PhD Thesis, İstanbul Technical University, Nuclear Energy Institute, İstanbul.

[6] Beck, H.L., 1982 The Physics of Environmental Gamma Radiation Fields, The Natural Radiation Environment II. USERDA Conf.720805-P2, 101-104.

[7] Şahin, S., 2009. The Change of Radon in the Sivrice Fault Zone and Natural Radioactivity, Frrat University Institute of Science and Technology, PhD Thesis, Elazığ.

[8] LUDLUM, 2012. Model 44-10 Gamma Scintillator, Ludlum Measurements, Inc., Texas.

[9] Şahin Bal, S., and Karatepe, S., 2015. Determination of Environmental Gamma Radiation in Bitlis, EPJ Web of Conferences, 100, 04002.

[10] Şahin, S., Niksarlıoğlu, S., and Yılmaz, M., 2010. The Measurement of Environmental Gamma Radiation in the Firat University Campus (Elazığ), Firat Univ, Joumal of Science, 22 (2), 101-107.

[11] UNSCEAR, 1993. Sources and effects of ionizing radiation. Report to General Assembly, with Scientific Annexes. United Nations, New York. 